\title{
ALLOY 718 LARGE INGOTS STUDIES
}

\author{
Carlo Malara ${ }^{1}$, John Radavich ${ }^{2}$ \\ ${ }^{1}$ Foroni S.p.A., Via A. Colombo n. 285, Gorla Minore (VA), I-21055, Italy \\ ${ }^{2}$ Micro-Met Laboratories, 209 North Street, West Lafayette, IN 47906, USA \\ Keywords: Alloy 718, Large Ingots, AOD, SEM
}

\begin{abstract}
Alloy 718 VAR ingots of $860 \mathrm{~mm}$ (34 inches) in diameter were successfully melted and processed to billets and finished products in the range from 355 to $660 \mathrm{~mm}$ (14 to 26 inches) in diameter. A special melting route was followed resulting in a quadruple melted material: initial melting of raw materials in an electric arc furnace, liquid metal refining in an Argon-Oxygen Decarburization (AOD) converter, air pouring into molds and solidification, vacuum melting of AOD ingots and pouring into electrodes using a Vacuum Induction Degassing and Pouring (VIDP) furnace and double Vacuum Arc Remelting (VAR) computer-controlled processing. Double VAR ingots were homogenized and hot forged on a $50 \mathrm{MN}$ open-die, computercontrolled hydraulic forging press to ultrasonic sound billets. Billets were macro examined and show no evidence of freckles, white spots, radial segregations or ring pattern. Billet microstructure showed an uniform grain size throughout the billet cross-section. Proper solution annealing and age hardening resulted in microstructure and mechanical properties matching requirements of both aerospace and oil patch specifications. Results of this study demonstrate the feasibility of large alloy 718 billets and finished bars from thirty-four inches ingots of comparable quality to billets and bars manufactured from standard twenty inches ingots and present an opportunity for manufacturing larger wrought products of alloy 718 for power generation and aerospace applications.
\end{abstract}

\section{Introduction}

Since its first application in the 1960's, alloy 718 has become the most widely used superalloy in the world. Large quantities of this alloy have been and continue to be used in the aerospace, power generation and petrochemical industries. Great strides have been made in the improving and controlling the quality of alloy 718 through minor chemistry variation and through controlled processing changes. Melting improvements have minimized or eliminated segregation; i.e. freckles and white spots. Control of hot processing operations has produced uniform fine grained bar and billet for manufacturing many different types of components [1,2]. Today, alloy 718 quality barely resembles the alloy 718 first produced in the 1960's and many efforts are made to further expand the usage of this material by manufacturing larger and larger starting billet sizes. This presents a problem since the goal of achieving alloy 718 billets from large ingots free of segregations in terms of freckles, white spots and the TCP phases such as Laves etc. has been elusive up to now and, for applications requiring high quality product, most alloy 718 produced today is limited to a starting ingot size of $685 \mathrm{~mm}$ (twenty-seven inches) in diameter [3]. Even triple melting, i.e. vacuum induction melting (VIM) plus electroslag remelting (ESR) plus vacuum arc (VAR) has not yet been able to provide segregation-free material in starting ingot sizes of thirty-three to thirty-five inches in diameter or larger [4].

At Foroni S.p.A., an R\&D programme was started in early 1990's to manufacture large alloy 718 billets and finished products starting from VAR ingots of thirty-four inches in diameter. Results of these investigations are herein described. 


\section{Manufacturing Process}

Alloy 718 billets and finished products in the range from fourteen to twenty-six inches in diameter were successfully manufactured starting from double VAR ingots of thirty-four inches in diameter and approximately 12 tons in weight. A special melting route was followed resulting in a quadruple melted material: initial melting of raw materials in an electric arc furnace, refining of the liquid metal in an Argon-Oxygen Decarburization (AOD) converter, air pouring into round molds and solidification, vacuum melting of AOD ingots and pouring into electrodes using a Vacuum Induction Degassing and Pouring (VIDP) furnace and double VAR computer-controlled processing.

Initial melting of alloy 718 was done in a 50 ton electric arc furnace using high quality raw materials. After an appropriate slagging practice, the molten metal is transferred to an argon oxygen decarburization (AOD) converter of the same capacity, which improves the alloy cleanliness as a result of thorough desulfurization and deoxidation while providing a tight and reproducible chemical composition. Decarburization to low carbon levels is controlled by the argon-oxygen gas ratio, gas flow rate, time and temperature. After the molten bath in the AOD is deslagged, the liquid metal is air poured into molds and solidified by air cooling.

AOD ingots, already in compliance with applicable chemical requirements, are stripped from the molds, ground and transferred to a 20 tons VIDP furnace only for a first degassing, especially for hydrogen and nitrogen, by vacuum melting and pouring into clean, inspected, hot-topped round molds of thirty-one inches in diameter. After solidification, electrodes are stripped from the molds, conditioned by grinding to remove surface defects and cropped to remove the hot top and any observed pipe. Conditioned electrodes are stubbed by welding stubs of alloy 718. After cleaning and solvent degreasing, stubbed electrodes are double VAR processed into seamless forged copper crucibles of thirty-four inches in diameter using a fully computer-controlled process that maintains melting parameters at prefixed values.

The average chemical composition of more than 20 ingots of thirty-four inches in diameter manufactured with the above described melting practice is given in Table I.

Table I. Average chemical composition of $860 \mathrm{~mm}$ (34 inches) double VAR ingots of alloy 718

\begin{tabular}{|c|c|c|c|c|c|}
\hline Element & Content (\%wt) & Element & Content (\%wt) & Element & Content (\%wt) \\
\hline $\mathrm{Ni}$ & 54,58 & $\mathrm{Si}$ & 0,12 & $\mathrm{~B}$ & 0,0042 \\
\hline $\mathrm{Cr}$ & 18,57 & $\mathrm{Mn}$ & 0,07 & $\mathrm{~S}$ & 0,0004 \\
\hline $\mathrm{Fe}$ & 17,10 & $\mathrm{~V}$ & 0,05 & $\mathrm{Sn}$ & $<0,005$ \\
\hline $\mathrm{Nb}$ & 5,05 & $\mathrm{Cu}$ & 0,043 & $\mathrm{Ta}$ & $<0,005$ \\
\hline $\mathrm{Mo}$ & 3,00 & $\mathrm{Co}$ & 0,029 & $\mathrm{Mg}$ & $<0,001$ \\
\hline $\mathrm{Ti}$ & 0,89 & $\mathrm{~W}$ & 0,02 & $\mathrm{~Pb}$ & $<0,0005$ \\
\hline $\mathrm{Al}$ & 0,44 & $\mathrm{P}$ & 0,0084 & & \\
\hline $\mathrm{C}$ & 0,020 & $\mathrm{~N}$ & 0,0064 & & \\
\hline
\end{tabular}

Double VAR ingots are subjected to a long homogenization treatment in the temperature range from 1150 to $1190{ }^{\circ} \mathrm{C}$ to minimize element segregation in the ingot and eliminate TCP phases such as Laves phases. Homogenized ingots are hot forged at $1100{ }^{\circ} \mathrm{C}$ on a state of the art $50 \mathrm{MN}$ open-die hydraulic forging press fully integrated with dual manipulators to produce ultrasonic sound billets of twenty to twenty-six inches in diameter. The hot working process is carried out in an almost isothermal way by a computer-controlled process that maintain deformation parameters including deformation speed, penetration depth and number of passes at prefixed values. Several forging heats are required to reduce the thirty-four inches ingot to a billet of twenty to twenty-six inches in diameter. 


\section{Ingot Structure}

Ingot macro- and microstructure in the as-cast condition were characterized by optical microscope and SEM investigations of several full cross-section slices cut at top, bottom and middle of thirty-four inches VAR ingots.

Figure 1 shows the macrostructure of a slice removed from the middle of the ingot after turning and then etching with aqua regia: a coarse structure with dendrites was revealed.

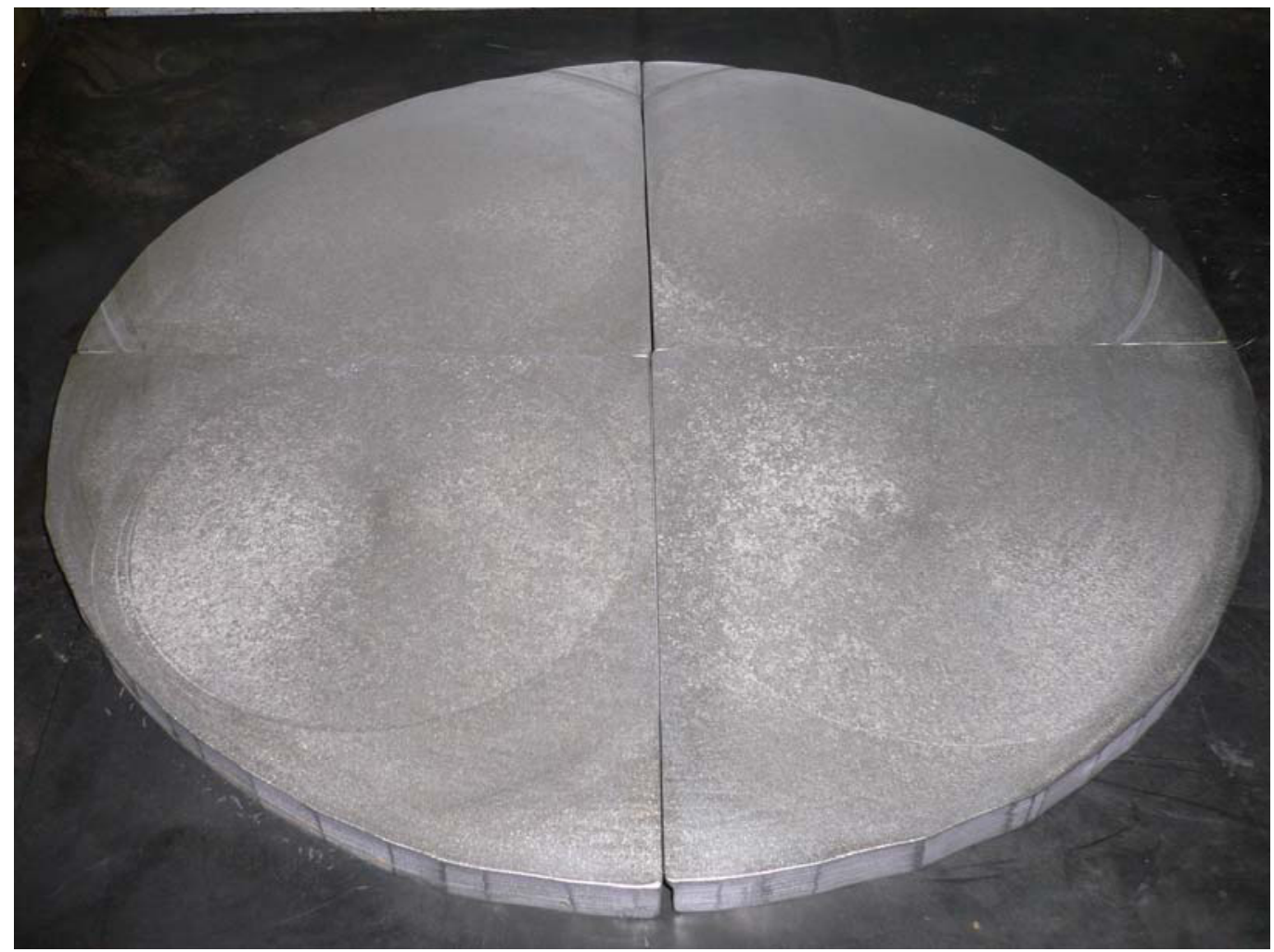

Figure 1. Macroetch examination of a slice cut from the middle of alloy 718 VAR ingot of 860 $\mathrm{mm}(34$ ") in diameter in the "as-cast" condition.

The microstructure at center, mid radius and surface locations of the slice shown in Figure 1 is shown in Figure 2. The microstructure results to be consistent and uniform throughout the ingot cross-section.
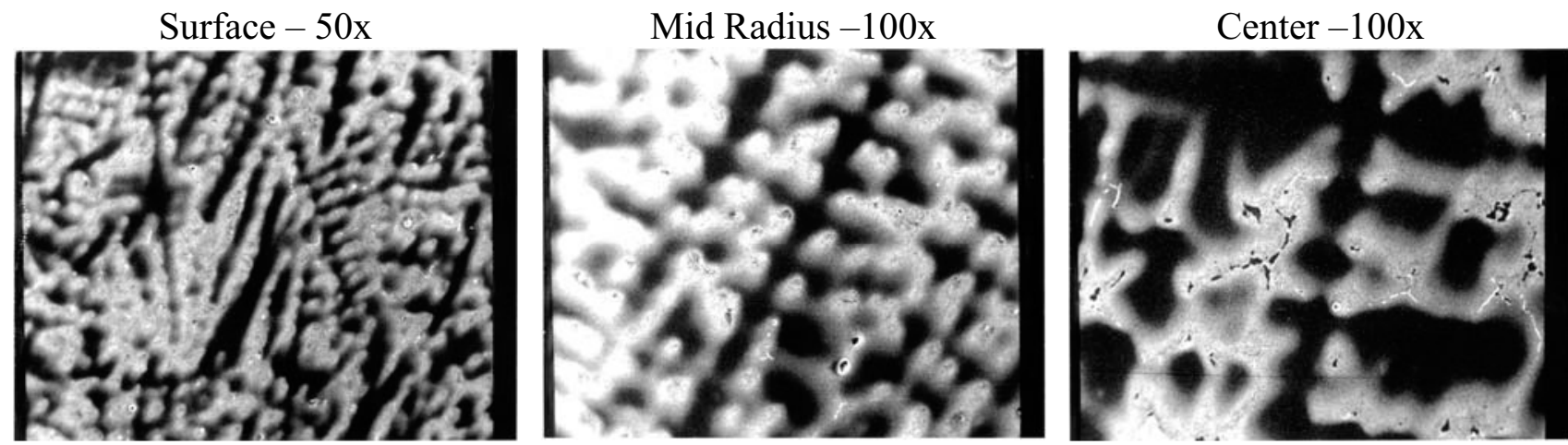

Fig. 2. Microstructure of electropolished specimens removed at surface, mid radius and center locations of the middle slice shown in Figure1. Examination performed using SEM. 
The center location show large dendrite arm spacing (DAS) and a $\mathrm{Nb}$-free dark matrix. Segregation areas are large and show delta needles tapering off into fine precipitates (Figure 3). The gray periphery areas contain very small particles at $30 \mathrm{~K}$.

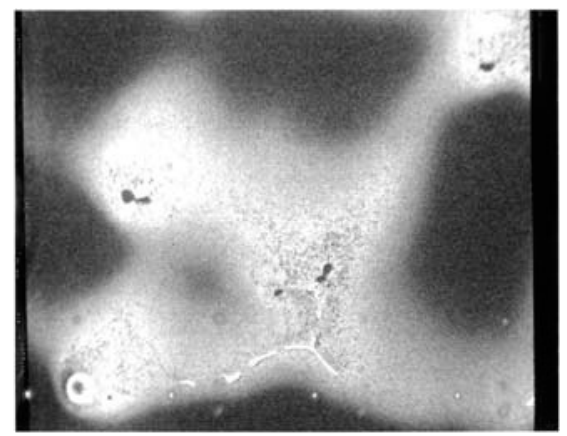

$300 x$

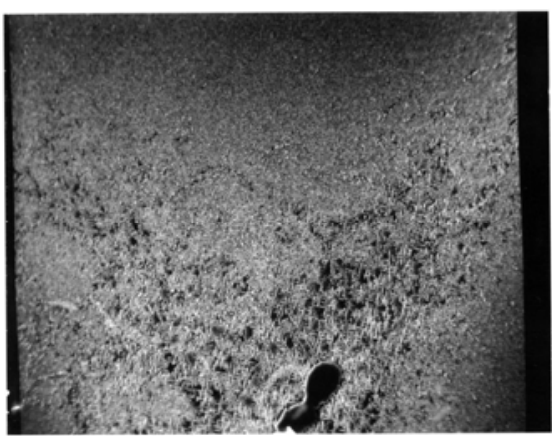

1000x

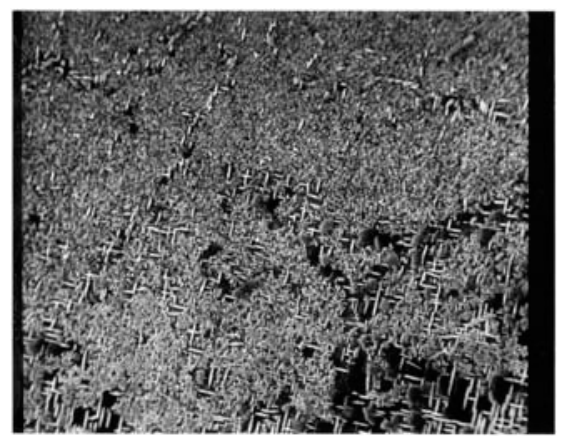

$3000 x$

Fig. 3. Details of microstructure at center of the middle slice shown in Figure 1 using SEM at different magnifications.

At mid radius, DAS is much smaller and there are more areas which show presence of $\mathrm{Nb}$. The segregation is less as seen by the closeness of the white areas. The amount of the needle phase is less than at center location (Figure. 4). Areas between the segregation islands show presence of large particles.

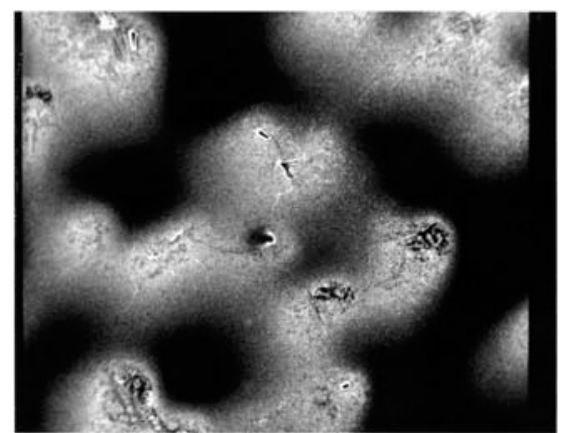

$300 x$

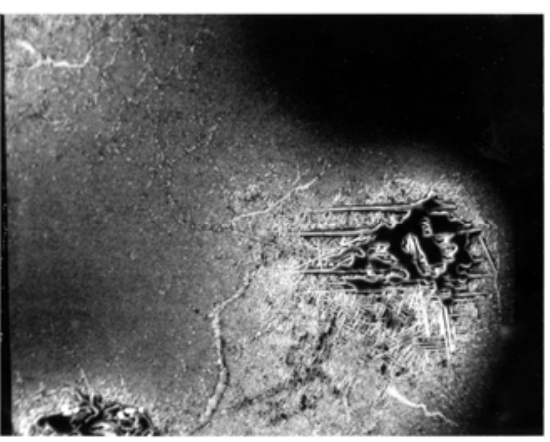

$1000 x$

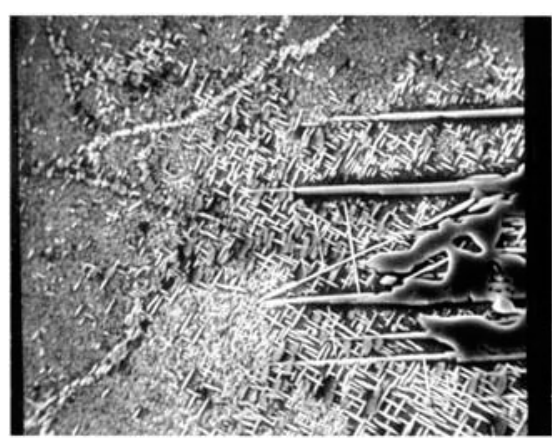

$3000 x$

Figure 4. Details of microstructure at mid radius of the middle slice shown in Figure 1 using SEM at different magnifications.

The edge, near surface, location exhibits less segregation as shown by the smaller DAS and more white areas. Fewer needles are present as a result of faster cooling as would be expected (see Figure 5).

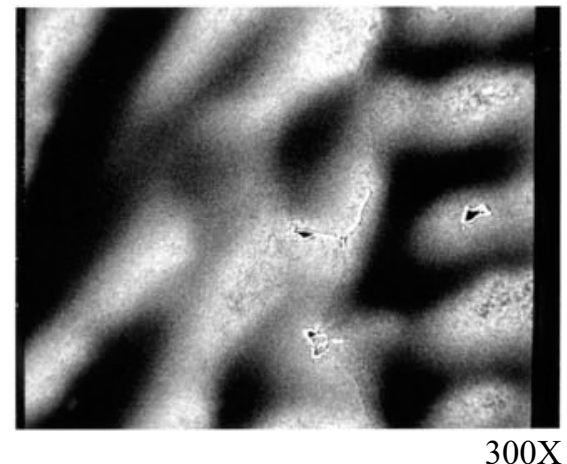

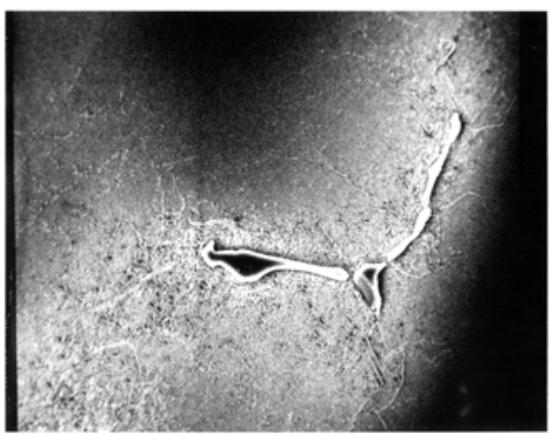

$1000 X$

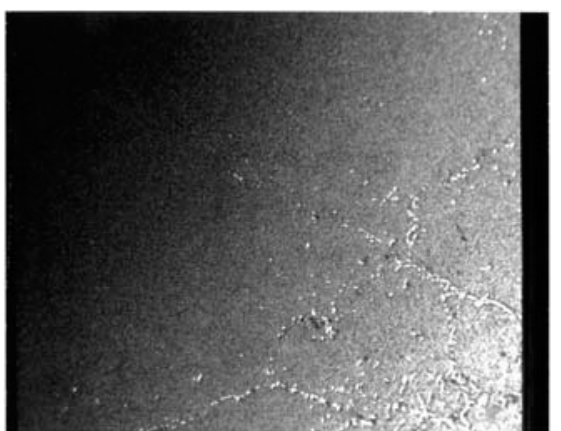

$3000 \mathrm{X}$

Figure 5. Details of microstructure at surface of the middle slice shown in Figure 1 using SEM at different magnifications. 
The effectiveness of ingot homogenization treatment can be assessed from Figure 6, which shows a microstructure free from segregations and with some porosity up to $50 \mu \mathrm{m}$ as a result of complete dissolutioning of TCP's.

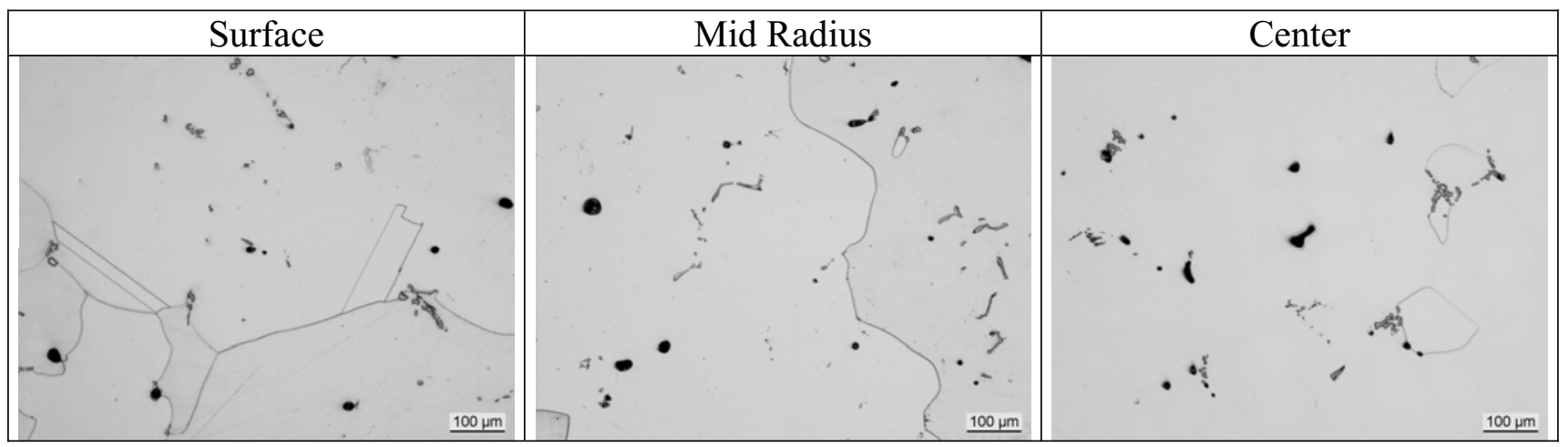

Figure 6 - Microstructure at surface, mid radius and center of a cross-section of homogenized double VAR ingot of $860 \mathrm{~mm}$ (34") in diameter under light microscope (specimens removed from the same slice shown in Figure 1 and mechanically polished).

\section{Billet Evaluation}

Billets of twenty to twenty-six inches in diameter obtained by hot working alloy 718 VAR ingots of thirty-four inches in diameter were macro examined at top, bottom and middle position of the parent ingot and showed no evidence of freckles, white spots, radial segregations or ring pattern (see Figure 7).

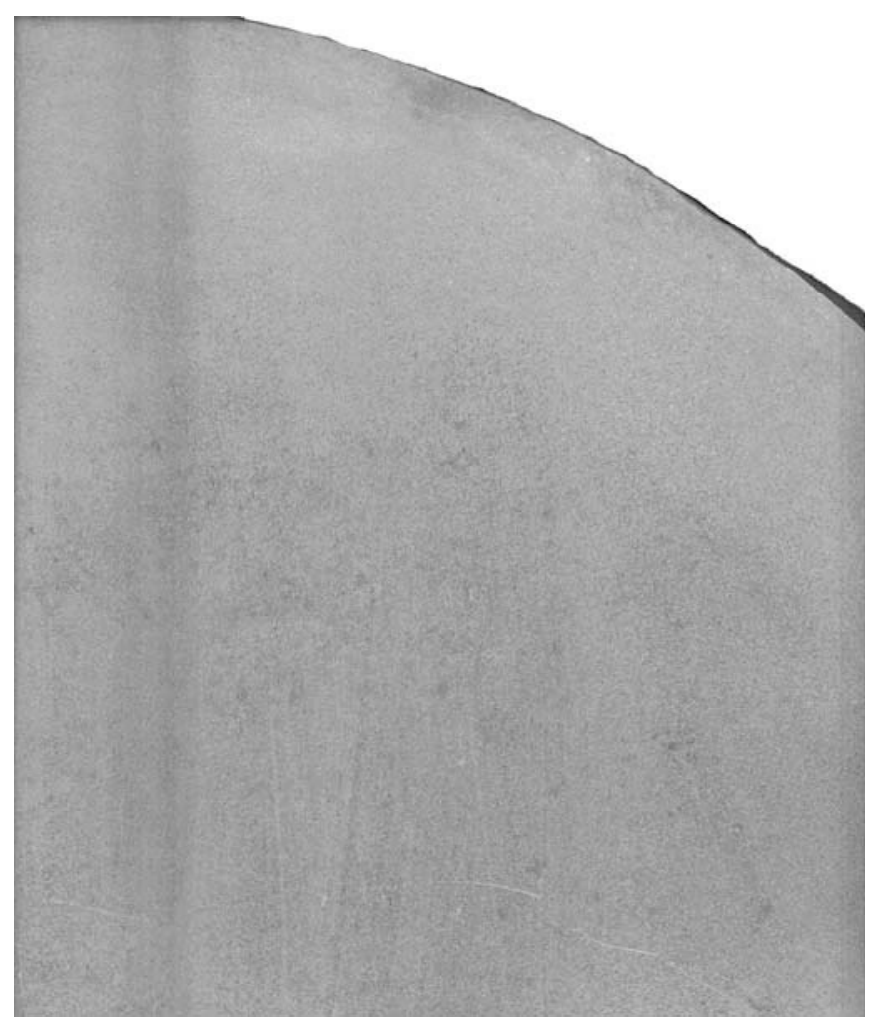

Figure 7. Macro examination of an alloy 718 billet of $660 \mathrm{~mm}$ (26 inches) in diameter forged from an $860 \mathrm{~mm}$ (34 inches) double VAR ingot (slice cut from the middle position of the parent ingot, turned and etched with aqua regia). 
Billet microstructure showed a uniform grain size throughout the billet cross-section with normal titanium carbo-nitride (TiCN) stringers and some porosity up to $50 \mu \mathrm{m}$ (Figures 8 and 9). No duplex grain size or necklace structures were observed.

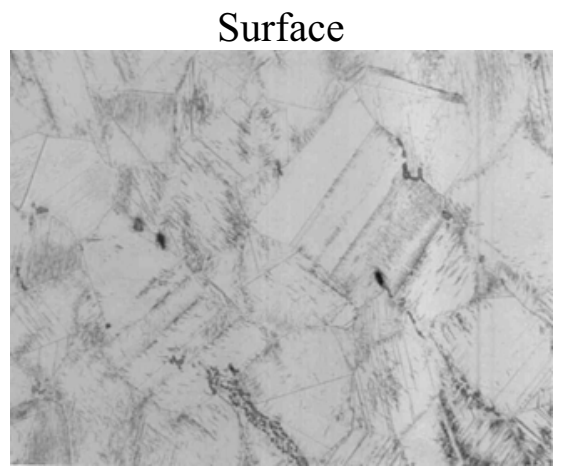

Grain Size: ASTM No. 1-2 (00)

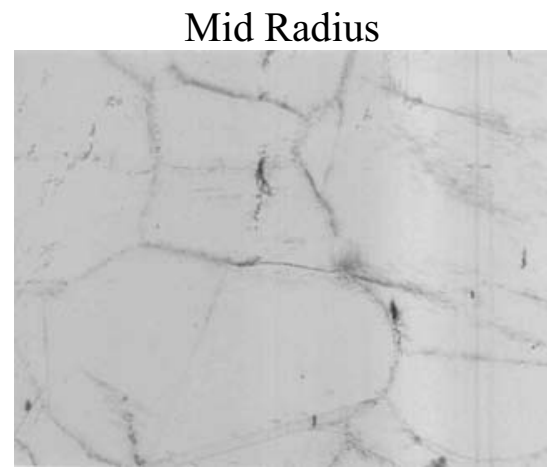

Grain Size: ASTM No. $<00-1$

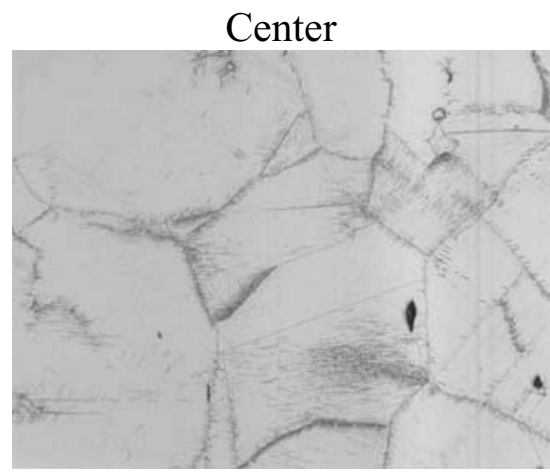

Grain Size: ASTM No. 0-1

Figure 8. Microstructure at center, mid radius and surface of the billet of $660 \mathrm{~mm}$ (26 inches) in diameter shown in Figure 7 under light microscope at 100X.

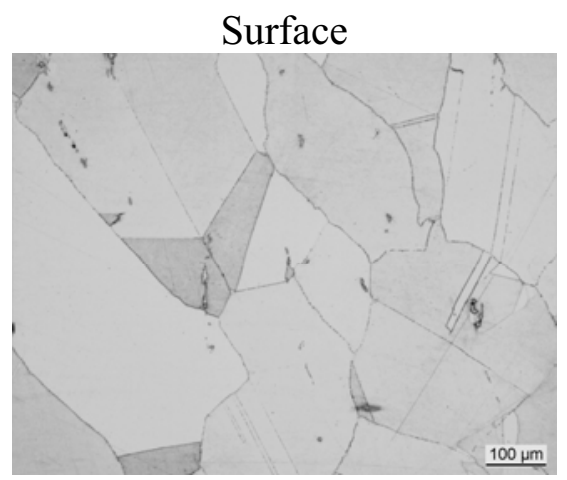

Grain Size: ASTM No. 1-2
Mid Radius

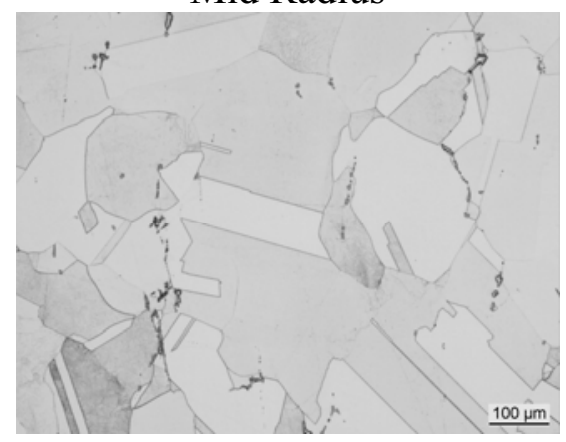

Grain Size: ASTM No. 3 (2)
Center

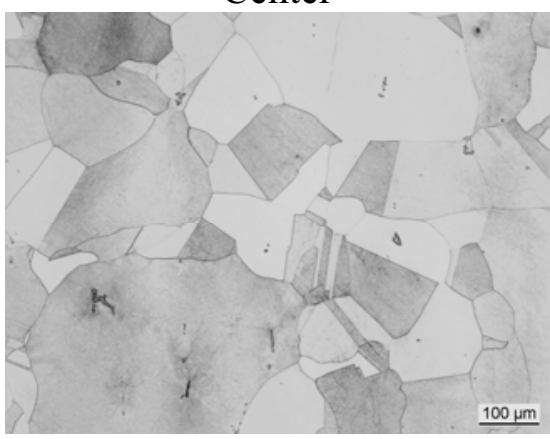

Grain Size: ASTM No. 3 (2)

Figure 9. Microstructure at center, mid radius and surface of an alloy 718 billet of $508 \mathrm{~mm}(20$ inches) in diameter forged from an $860 \mathrm{~mm}$ (34 inches) double VAR ingot under light microscope.

To check for delta phase segregation, annealed center and mid-radius specimens of the billet shown in Figure 9 were held in the delta precipitation temperature range at $955^{\circ} \mathrm{C}$ for 4 hours. No delta phase banding was observed in the mid-radius location, as illustrated in Figure 10. Light delta phase banding was observed in the center location of the $508 \mathrm{~mm}$ billet as illustrated in Figure 11. An extraction was subsequently conducted on a sample from the center location, and showed no presence of Laves phase or any other TCP phases. 




Fig. 10. Mid radius specimen at 50x of billet of $508 \mathrm{~mm}$ (20 inches) in diameter given in Fig. 9 showing no delta phase

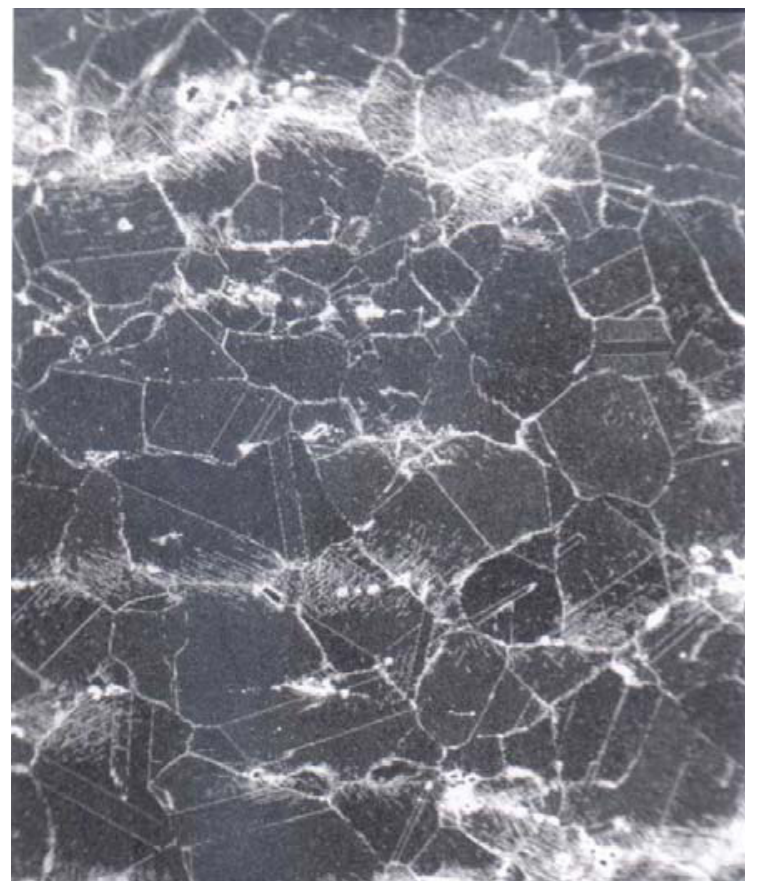

Fig. 11. Center specimen at 50x of billet of $508 \mathrm{~mm}$ (20 inches) in diameter given in Fig. 9 showing light delta phase

\section{Properties of finished bars}

Finished bars of fourteen to twenty inches in diameter were manufactured from billets described above by further hot working and proper solution annealing and age hardening. The resultant microstructure and mechanical properties matched requirements of both aerospace and oil patch specifications.

Figure 12 and Table II show microstructure and mechanical properties of a finished bar of twenty inches in diameter heat treated to AMS 5663 (solution annealed at $980{ }^{\circ} \mathrm{C}$ and age hardened at $718 / 621{ }^{\circ} \mathrm{C}$ ). The microstructure is uniform throughout the full cross-section of the bar without topological duplex grain size like necklace, banding or randomly distributed large grains. Normal TiCN stringers are observed especially at center and mid radius locations. Mechanical properties match requirements of AMS 5663 at room temperature as well as $649{ }^{\circ} \mathrm{C}$.

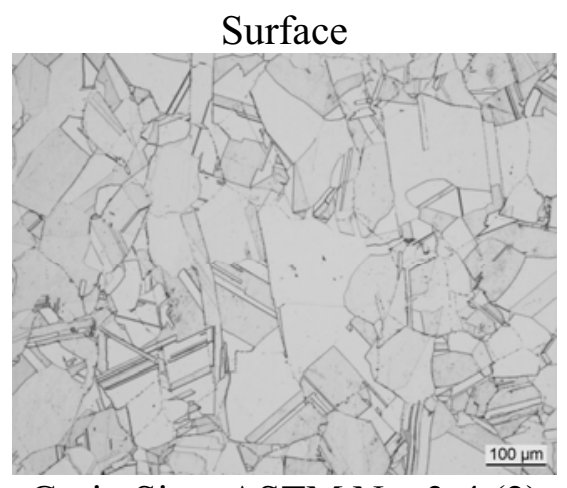

Grain Size: ASTM No. 3-4 (2)

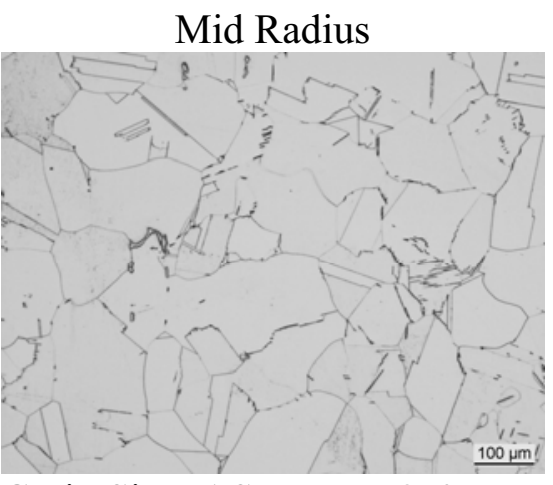

Grain Size: ASTM No. 3-4

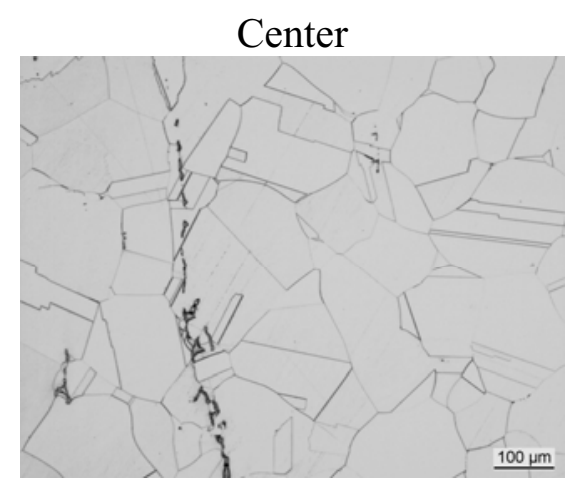

Grain Size: ASTM No. 3

Figure 12 - Microstructure at center, mid radius and surface of a $508 \mathrm{~mm}$ (20 inches) finished bar heat treated to AMS 5663 (solution annealed at $980{ }^{\circ} \mathrm{C}$ and age hardened at $718 / 621{ }^{\circ} \mathrm{C}$ ). 
Table. II. Mechanical properties at mid radius in the transverse orientation of a $508 \mathrm{~mm}(20$ inches) finished bars heat treated to AMS 5663 (solution annealed at $980{ }^{\circ} \mathrm{C}$ and age hardened at $\left.718 / 621^{\circ} \mathrm{C}\right)$.

\begin{tabular}{|c|c|c|c|c|c|}
\hline Temperature & Yield Strength & $\begin{array}{c}\text { Tensile } \\
\text { Strength }\end{array}$ & Elongation & $\begin{array}{c}\text { Reduction of } \\
\text { Area }\end{array}$ & Hardness \\
\hline${ }^{\circ} \mathrm{C}\left({ }^{\circ} \mathrm{F}\right)$ & $\mathrm{MPa}(\mathrm{ksi})$ & $\mathrm{MPa}(\mathrm{ksi})$ & $\%$ & $\%$ & HB $(\mathrm{HRC})$ \\
\hline Room Temp. & $1098(159)$ & $1248(181)$ & 16.0 & 22 & $401(40)$ \\
\hline $649(1200)$ & $893(130)$ & $976(142)$ & 16.5 & 27.8 & - \\
\hline
\end{tabular}

Figure 13 and Table. III show microstructure and mechanical properties of a finished bar of sixteen inches in diameter heat treated to NACE MR0175 and API 6A718 for oil applications (solution annealed at $1030{ }^{\circ} \mathrm{C}$ and age hardened at $787^{\circ} \mathrm{C}$ for about 7 hours). As for the above described bar, the microstructure is uniform throughout the full cross-section of the sixteen inches bar with clean grain boundaries and normal TiCN stringers and without topological duplex grain size and acicular delta in and growing from grain boundaries. Mechanical properties match all strength, ductility and impact resistance requirements of the most advanced standards applicable to this product like NACE MR0175 and API 6A718 specifications.

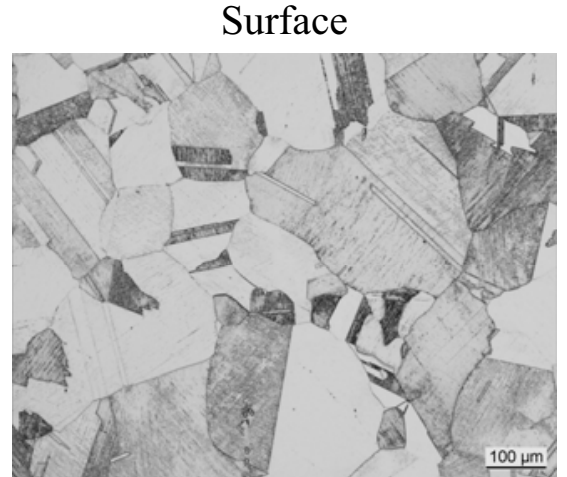

Grain Size: ASTM No. 3 (2)
Mid Radius

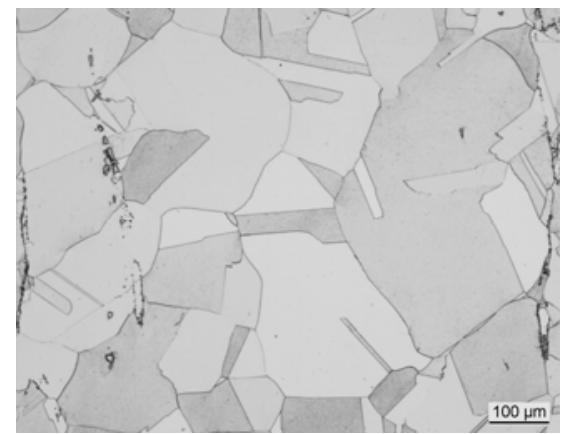

Grain Size: ASTM No. 2-3
Center

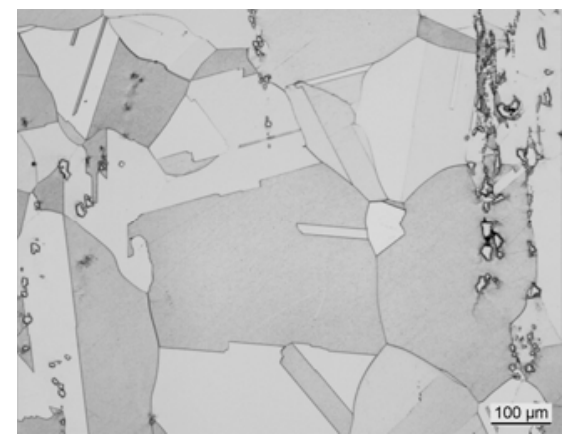

Grain Size: ASTM No. 2-3

Figure 13 - Microstructure at center, mid radius and surface of a $406.4 \mathrm{~mm}$ (16 inches) finished bar heat treated to NACE MR0175 and API 6A718 (solution annealed at $1030{ }^{\circ} \mathrm{C}$ and age hardened at $787^{\circ} \mathrm{C}$ for about 7 hours).

Table III. Mechanical properties at mid radius of a $406.4 \mathrm{~mm}$ (16 inches) finished bar heat treated to to NACE MR0175 and API 6A718 for oil applications (solution annealed at $1030{ }^{\circ} \mathrm{C}$ and age hardened at $787^{\circ} \mathrm{C}$ for about 7 hours).

\begin{tabular}{|c|c|c|c|c|c|c|c|c|}
\hline \multicolumn{4}{|c|}{$\begin{array}{l}\text { Tensile properties in the longitudinal direction } \\
\text { @ room temperature }\end{array}$} & \multirow[t]{2}{*}{ Hardness } & \multicolumn{4}{|c|}{$\begin{array}{l}\text { Average CVN Impact Resistance @ } \\
-60^{\circ} \mathrm{C}\left(76^{\circ} \mathrm{F}\right)\end{array}$} \\
\hline $\begin{array}{l}\text { Yield } \\
\text { Strength }\end{array}$ & $\begin{array}{l}\text { Tensile } \\
\text { Strength }\end{array}$ & Elong. & $\begin{array}{l}\text { Reduction of } \\
\text { Area }\end{array}$ & & Impac & values & & $\begin{array}{l}\text { ral } \\
\text { asion }\end{array}$ \\
\hline \multirow[t]{2}{*}{ MPa (ksi) } & $\mathrm{MPa}(\mathrm{ksi})$ & $(\%)$ & $(\%)$ & (HRC) & $J(f$ & -lbs) & $\mathrm{mm}$ & mils) \\
\hline & & & & & Long. & Transv. & Long. & Transv. \\
\hline 931 (135) & $1200(174)$ & 27 & 36.6 & 37 & $77(57)$ & $51(38)$ & $\begin{array}{l}0.82 \\
(32)\end{array}$ & $\begin{array}{l}0.55 \\
(22)\end{array}$ \\
\hline
\end{tabular}


Finished bars up to sixteen inches in diameter met the ultrasonic examination requirements of AMS-STD-2154 Class C, that is no single discontinuity with an indication greater than the response from a reference flat-bottom hole of $2 \mathrm{~mm}(5 / 64$ inches) and no loss of back reflection greater than 50\%. Larger bars up to twenty inches in diameter met the ultrasonic requirements of API 6A PSL4, i.e. no single indications exceeding the reference distance-amplitude-curve (DAC) based on $6.4 \mathrm{~mm}$ (1/4 inches) flat bottom hole, no multiple indications exceeding $50 \%$ of the reference DAC and no continuous clusters of indications on the same plane.

\section{Conclusions}

Progress to date indicates that it is feasible to manufacture on an industrial scale process large alloy 718 billets up to twenty-six inches and finished bars up to twenty inches in diameter starting from $860 \mathrm{~mm}$ (thirty-four inches) diameter VAR ingots that are comparable in quality to material manufactured from the industry standard $508 \mathrm{~mm}$ (twenty inches) diameter VAR ingots. One of the key role factors achieving this result is refining the liquid metal by the AOD process which improves the alloy cleanliness as a consequence of thorough desulfurization and deoxidation while providing a tight and reproducible chemical composition The availability of such large high quality billets is significant and presents an opportunity for forging large land based and aircraft engine disks and other large parts from alloy 718. Similarly, large components may be manufactured from large finished bars by machining thereby avoiding hot upset forge operations.

\section{References}

[1] R. E. Schafrik, D. D. Ward and J. R. Groh, "Application of Alloy 718 in GE Aircraft Engines: Past, Present and Next Five Years" Superalloy 718, 625, 706 and Various Derivatives, ed. E. A. Loria (The Mineral, Metals \& Materials Society, 2001), 1-11.

[2] D. F. Paulonis and J. J. Schirra, "Alloy 718 at Pratt \& Whitney - Historical Perspectives and Future Challenges", Superalloy 718, 625, 706 and Various Derivatives, ed. E. A. Loria (The Mineral, Metals \& Materials Society, 2001), 13-23.

[3] S.V. Thamboo et al., "Large Diameter 718 Ingots for Land-based Gas Turbines", Superalloy 718, 625, 706 and Various Derivatives, ed. E. A. Loria (The Mineral, Metals \& Materials Society, 2001), 57-70.

[4] D. G. Evans and M. Fahrmann, "A Study of the Effect of Electro-Slag Re-melting Parameters on the Structural Integrity of Large Diameter Alloy 718 ESR Ingot”, Superalloys 2004, ed. K. A. Green et al. (The Mineral, Metals \& Materials Society, 2004), 507-515. 